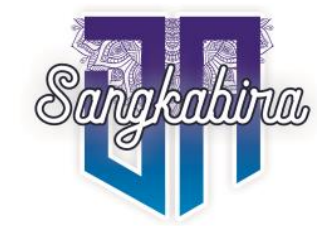

Vol. 2, No. 1, Desember 2021

\title{
EDUKASI HYBRID ENTREPRENEURSHIP PADA MAHASISWA POLITEKNIK NEGERI MADIUN UNTUK MENAMBAH WAWASAN KEWIRAUSAHAAN
}

\author{
Hifzhan Frima Thousani \\ Program Studi Administrasi Bisnis Politeknik Negeri Madiun \\ thousani@pnm.ac.id \\ Ridho Muarief \\ Program Studi Administrasi Bisnis Politeknik Negeri Madiun \\ ridho.muarief@pnm.ac.id \\ Priyanto \\ Program Studi Administrasi Bisnis Politeknik Negeri Madiun \\ pri.jpg@pnm.ac.id
}

Info Artikel

Diterima:

05-10-2021

Direvisi:

24-12-2021

Diterbitkan:

24-12-2021

\begin{abstract}
Abstrak
Terdesak oleh pemenuhan kebutuhan yang meningkat, beberapa orang yang menjadi karyawan dan mendapat gaji dalam periode waktu tertentu memilih untuk memiliki pekerjaan tambahan. Diantaranya memilih mengelola bisnis sebagai upaya mencari pendapatan tambahan. Disisi lain, mahasiswa cenderung menjadi job seeker sesuai prodi yang dijalani daripada menjadi job creater setelah lulus. Mengelola bisnis sekaligus menjadi karyawan bisa menjadi solusi tapi menjalankan lebih dari satu pekerjaan memerlukan rencana strategis demi mampu menjalankan tanggungjawab secara penuh. Mahasiswa dipilih sebagai target supaya mampu menumbuhkan dan mengembangkan minat sebagai wirausaha dalam menciptakan lapangan pekerjaan. Melihat dari masalah tersebut maka diselenggarakan webinar edukasi mengenai hybrid entrepreneurship yaitu mengelola bisnis sekaligus menjalani pekerjaan utama sebagai karyawan perusahaan. Metode yang digunakan untuk menyampaikan materi adalah lecture dengan target peserta webinar adalah mahasiswa Politeknik Negeri Madiun. Hasil yang diharapkan dari webinar ini adalah mahasiswa mampu memiliki pengetahuan mengenai hybrid entrepreneurship untuk digunakan dalam pengambilan keputusan.

Kata Kunci: hybrid entrepreneur, karyawan, bisnis, mahasiswa, moonlighting, pekerjaan ganda
\end{abstract}

DOI: $10.29303 / a b d i m a s s a n g k a b i r a . v 2 i 1.61$ 


\section{Pendahuluan}

Bagi seseorang yang tidak menyukai pengambilan resiko yang besar, pekerjaan sebagai karyawaan mampu menjamin stabilitas ekonomi dengan gaji perbulan yang didapat namun seiring dengan peningkatan kebutuhan, terkadang gaji sebagai karyawan kurang bisa memenuhi kebutuhan maupun keinginan maka dari itu kini mulai bermunculan karyawan yang memiliki pekerjaan sampingan, bisa jadi merangkap menjadi karyawan dibidang lain maupun memiliki bisnis sampingan. Bisnis sampingan bisa saja memberikan sumbangsih finansial untuk memenuhi kebutuhan dan keinginan bahkan bisnis sampingan bisa jadi lebih berkembang dan menghasilkan pendapatan yang lebih besar daripada gaji yang didapatkan dari pekerjaan sebagai karyawan. Aktifitas memiliki pekerjaan sampingan ini cukup banyak diminati. Tercatat dalam Konstantinos (2017) bahwa pada tahun 2015, 4,9\% pekerja di AS menyatakan bahwa mereka melakukan pekerjaan lain selain pekerjaan utama merek kemudian ada Islandia $12 \%$, $10 \%$ di Norwegia, 9\% di Swedia, dan 6\% hingga 7\% di Finlandia dan Denmark - serta di Belanda, dengan tingkat 9\%. Disisi lain Indonesia Family Life Survey (IFLS), mengungkapkan bahwa kepemilikan pekerjaan ganda cukup lazim di Indonesia, terhitung setidaknya 20\% dari responden panel yang bekerja antara tahun 1993 dan 2007.

Situasi dimana seseorang memiliki lebih dari satu pekerjaan biasa disebut Moonlighting yaitu ketika seseorang tersebut memiliki satu pekerjaan utama dan menjalankan pekerjaan sampingan. Hal tersebut dilakukan demi penghidupan yang lebih baik melalui peningkatan pendapatan sehingga menciptakan kestabilan secara finansial serta menjadi jaminan finansial ketika karyawan tersebut kehilangan pekerjaan utama. Disisi lain, menjadi moonlighting memerlukan pengelolaan diri yang baik karena menjalani pekerjaan sama dengan memegang lebih dari satu tanggungjawab dan hal tersebut memiliki resiko tersendiri. Sebagai mana yang dijelaskan oleh Wilkinson dan Pickett (2009) bahwa walaupun teori ekonomi klasik menunjukkan bahwa peningkatan pendapatan adalah tujuan menjalankan ekonomi namun memungkinkan adanya konsekuensi yang merugikan prospek pertumbuhan jangka panjang, ditinjau dari kesejahteraan pribadi secara keseluruhan dan tingkat depresi yang dialami sehingga pekerjaan dilakukan secara tidak stabil.

Perkembangan teknologi dan globalisasi juga mempengaruhi kegiatan moonlighting karena kemudahan akses yang disajikan internet kini menjadikan orang-orang semakin fleksibel mengerjakan pekerjaan darimana saja, tidak terpaku dengan tempat. Bisnis online yang muncul pada era ini adalah salah satu bentuk hasil dari kemudahan akses internet. Menurut APJII (Asosiasi Penyelenggara Jasa Internet Indonesia) survei Data Statistik Pengguna Internet Indonesia periode 2019-kuartal II 2020 menunjukan jumlah pengguna internet di Indonesia hingga kuartal II tahun 


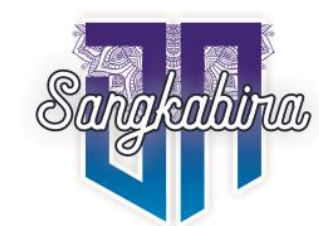

Vol. 2, No. 1, Desember 2021

ini naik menjadi 73,7 persen dari populasi atau setara 196,7 juta pengguna, hal tersebut dipandang peluang positif sebagai target pemasaran bisnis. Bisnis online yang tidak terpaku harus memiliki toko dan kemudahan akses pembelian barang melalui transaksi online memikat banyak orang untuk bergabung menjalankan bisnis online untuk memperoleh keuntungan, tidak terkecuali karyawan yang telah mendapatkan pekerjaan tetap pada suatu instansi.

Bisnis online yang dijalani oleh karyawan ini disebut hybrid entrepreneurship yaitu keadaan bisnis yang dijalani sementara pemilik bisnis memiliki pekerjaan selain mengelola bisnis itu sendiri sedangkan yang menjadi seseorang tersebut disebut hybrid entrepreneur. Menjadi hybrid entrepreneur bukanlah perkara mudah sebagaimana orang-orang terburuburu terjun dalam bisnis online karena kemudahan yang terlihat. Sebagaimana yang dijelaskan oleh Sarah dkk (2013) bahwa hybrid entrepreneur memiliki lebih banyak peran yang harus dihadapi karena kehidupan kerja mereka terdiri dari keduanya yaitu upah kerja dan menjalankan bisnis. Maka dari itu pengetahuan mengenai pengelolaan bisnis sampingan yang dilakukan oleh karyawan perlu dilakukan untuk memberi gambaran bagaimana proses pengelolaan bisnis bisa berjalan ketika pemilik bisnis sendiri mempunyai pekerjaan tetap yang utama yaitu sebagai karyawan. Hal ini untuk memudahkan adaptasi dan merencanakan langkah pengambilan keputusan dikemudian hari. Disisi lain, pengetahuan mengenai bisnis sampingan ini juga akan mengenalkan dunia wirausaha dan manfaatnya bagi sekitar karena bisnis yang dikelola dengan baik akan mampu berkembang dan berkemungkinan untuk melibatkan orang lain didalamnya, hal tersebut secara tidak langsung dapat membuka lapangan pekerjaan.

Mahasiswa sebagai citivas academia sebagai bibit penunjang dan pengembang ekonomi bangsa di masa depan mulai beberapa tahun terakhir telah diarahkan mendalami kewirausahaan untuk menciptakan lapangan pekerjaan. Sebagaimana yang dijelaskan oleh Tamriatin (2015) bahwa lulusan perguruan tinggi lebih diarahkan sebagai pencipta kerja (job creator) daripada menjadi pencari kerja (job seeker). Akan tetapi sebagaimana telah dijelaskan oleh Maulana (2018) realitas yang banyak ditemukan adalah mahasiswa setelah lulus nantinya mencari pekerjaan yang ideal yang dapat menjadi kebanggaan di dalam hidupnya. Dalam menangani masalah tersebut pada akhirnya terjadi fenomena hybrid entrepreneurship yaitu para alumni perguruan tinggi yang telah mendapatkan pekerjaan utama sebagai karyawan sesuai dengan pekerjaan ideal yang mereka inginkan sewaktu kuliah merangkap menjalani pekerjaan lain berupa mengelola bisnis sampingan. Untuk menjalani hal tersebut, diperlukan edukasi dan sosialisasi sejak dini supaya mahasiswa dapat memanajemen tanggungjawab dan waktu kedepan dalam menjadi hybrid 
entrepreneur supaya hal tersebut dapat berjalan secara maksimal dan mampu menjamin stabilitas finansial serta tidak menimbulkan dampak negatif yang dikhawatirkan terjadi. Dampak positif lebih lanjut sebagaimana diterangkan Konstantinos (2017) bahwa peneliti semakin mengakui bahwa seorang yang memiliki pekerjaan sampingan tidak hanya dilakukan oleh pekerja berpenghasilan rendah karena pengalaman dalam mengerjakan pekerjaan sampingan memvalidasi keterampilan karyawan dalam meningkatkan mobilitas kerja di pekerjaan utama serta merangsang aktivitas kewirausahaan di pasar tenaga kerja kontemporer.

Maka dari penjelasan diatas, penulis mengadakan edukasi kepada mahasiswa Politeknik Negeri Madiun khususnya pada anggota Unit Kegiatan Kewirausahaan mengenai hybrid entrepreneur dengan harapan bahwa ilmu yang diberikan dapat menjadi pertimbangan bagi mahasiswa dalam mengambil langkah menjadi wirausaha dimasa yang akan datang.

\section{Metode}

Metode yang digunakan dalam menyampaikan materi adalah secara cerama/lecture. Edukasi dilakukan secara online atau virtual yaitu berupa webinar melalui aplikasi zoom meeting yang dilaksanakan pada tanggal 24 September 2021 pada pukul 13.00 WIB dan berlangsung selama tiga jam. Webniar ini diikuti oleh mahasiswa Politeknik Negeri Madiun dan disampaikan oleh narasumber yang berpengalaman menjadi hybrid entrepreneur yaitu narasumber bekerja sebagai karyawan Angkasa Pura sekaligus menjadi pemilik dari bisnis Jual Beli Mobil "Garasi Sahabat". Output yang diharapkan dari webinar ini yaitu mahasiswa memahami materi yang disampaikan sehingga kedepan dapat mengambil langkah strategis ketika ingin menjadi hybrid entrepreneur. Pemahaman materi oleh peserta diukur dari feedback positif pada sesi tanya jawab. Sebagaimana dijelaskan Hardiyansyah (2015) bahwa positive feedback terjadi ketika pesan yang disampaikan oleh komunikator dapat diterima oleh komunikan dan mencapai saling pengertian, sehingga komunikan akan mendukung, mengiyakan, sepakat, setuju atas pesan. Hal tersebut dapat dilihat dari tindakan responsif peserta dalam mengajukan pertanyaan yang relevan dengan materi yang disampaikan pada sesi tanya jawab karena hal tersebut merupakan indikasi positif tingkat ketertarikan dan kepahaman peserta webinar.

\section{Hasil dan Pembahasan}

Isi pendidikan kewirausahaan berupa materi yang disajikan, dibahas, dan dikembangkan dalam kegiatan, sedangkan kegiatan dan metodenya meliputi perkuliahan, pelatihan, pembinaan, dan lomba kewirausahaan, serta inkubasi bisnis (Sumarno dkk, 2017). Dalam pelaksanaannya, tahap-tahap tersebut direalisasikan melalui webinar 


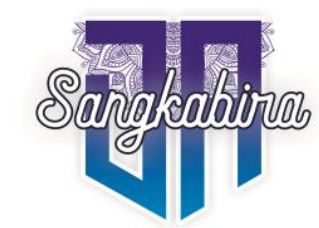

Vol. 2, No. 1, Desember 2021

dengan narasumber berpengalaman. Webniar diselenggarakan mengusung topik hybrid entrepreneur ini mengusung judul "Jadi karyawan dan Pengusaha? Bisa!". Poster dari webinar telah dipublikasi selama satu minggu sebelum acara dilaksanakan, dari jangka waktu tersebut didapatkan 90 orang sebagai peserta webinar yang sebagian besar merupakan anggota Unit Kegiatan Mahasiswa Kewirausahaan Politeknik Negeri Madiun. Peserta yang sudah terdaftar disatukan dalam satu wadah berupa grup Whatsapps untuk memudahkan penyampaian informasi terkait acara webinar.

Acara yang dijadwalkan dimulai pada waktu 13.00 WIB tepat dan login dibuka setengah jam sebelum waktu acara dimulai yaitu pada pukul 12.30 WIB, para peserta webinar masuk melalui akses link yang dibagikan di grup Whatsapp. Didalam link tersebut juga terdapat nomor virtual meeting dan password, setelah login peserta menunggu penyelenggara webinar untuk menerima permintaan masuk peserta supaya dapat bergabung dalam room zoom.

Acara dimulai dengan pembukaan yang disampaikan oleh pemandu acara yaitu penulis sendiri. Pada pembukaan, peserta diberi gambaran garis besar mengenai topik yang akan disampaikan. Mulai dari pengertian hybrid entrepreneur dan peluangnya dimasa sekarang serta alasan kenapa topik ini menjadi pilihan webinar yang disampaikan. Hal tersebut dilakukan dengan tujuan supaya materi yang akan disampaikan oleh narasumber dapat mudah diterima oleh peserta webinar. Penyampaian pembukaan berlangsung selama 20 menit yaitu dari jam 13.00-13.20 WIB.

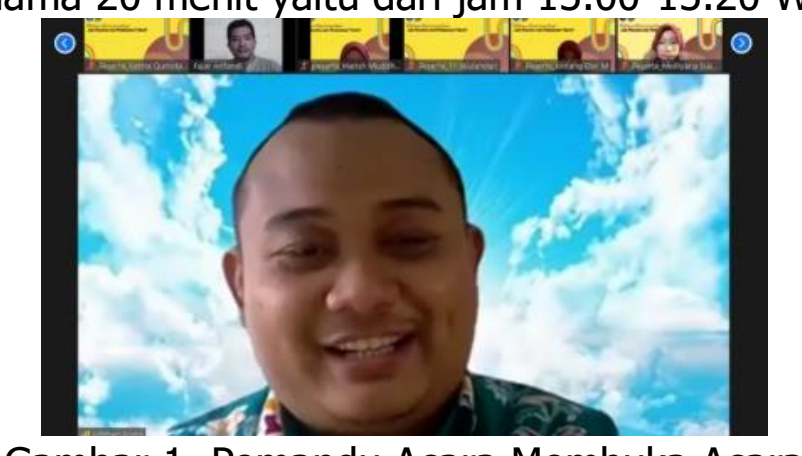

Gambar 1. Pemandu Acara Membuka Acara

(Sumber: Data Penulis)

Selanjutnya, narasumber dipersilakan menyampaikan materi untuk hari ini. Narasumber menyampaikan perkenalan dengan peserta sekaligus menguraikan perjalanannya hingga sampai dikeputusan menjadi hybrid entrepreneur. Ketika awal lulus kuliah, narasumber tidak langsung mendapat pekerjaan sebagai karyawan yang memiliki gaji atau upah yang tinggi, hal tersebut berdampak pada pendapatan yang diperoleh setiap bulan dari hasil gaji tidak sepenuhnya mampu untuk memenuhi kebutuhan dan keinginan sehari-hari. Selaras dengan Konstantinos (2017) yang menjelaskan bahwa salah satu faktor seseorang menjalani pekerjaan ganda adalah karena mencari pendapatan lebih. Materi disampaikan bahwa untuk 
sampai pada bisnis yang narasumber jalani saat ini, narasumber telah mencoba berbagai bidang bisnis. Mulai dari media bisnis yang dijalani yaitu offline dan online maupun jenis atau segmen bisnis yang dikelola yaitu kuliner, distribusi, dll hingga akhirnya sampai pada bisnis jual beli mobil online yang kini berhasil dan semakin berkembang. Hal tersebut dapat menjelaskan bahwa untuk terjun ke dunia bisnis, seseorang perlu mengambil resiko karena tidak semua bisnis yang dijalani akan langsung berhasil dan mendapat hasil dalam waktu singkat, selaras dengan yang dijelaskan Suryana (2013) bahwa kewirausahaan atau bisnis merupakan hasil dari disiplin proses.

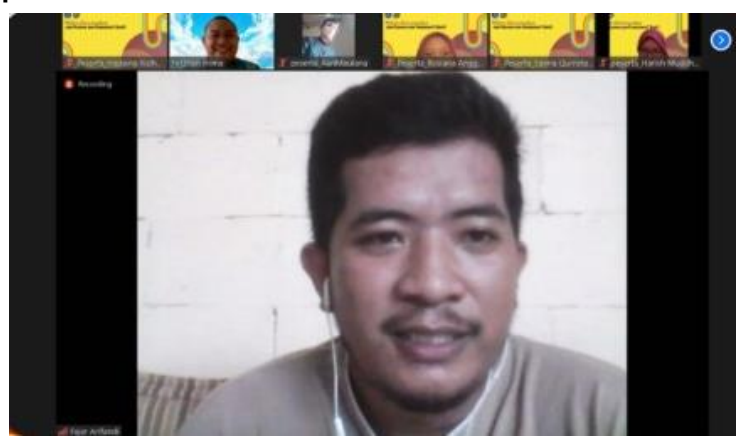

Gambar 2. Narasumber menyampaikan materi webinar

(Sumber: Data Penulis)

Materi yang disampaikan selanjutnya merupakan strategi yang dilakukan dalam menjadi hybrid entrepreneur. Dalam proses menjadi hybrid entrepreneur, ada dua kondisi yang memerlukan perhatian khusus yaitu sebelum menjalani bisnis dan ketika menjalani bisnis. Adapun hal yang perlu diperhatikan sebelum menjalani bisnis antara lain:

1. Ide dan peluang bisnis, ketika ide bisnis muncul maka perlu ada pertimbangan untuk menentukan peluang bisnis yang akan dijalani sehingga rencana dan gambaran bisnis bisa tergambar untuk mengembangkan bisnis dan mengantisipasi resiko.

2. Toleransi waktu, perlu diingat bahwa menjadi hybrid entrepreneur harus tetap mampu menjalankan tugas dan tanggungjawab sebagai karyawan atau pekerjaan utama sehingga perlu memerhatikan lebih dalam sejauh mana bisnis ini dapat berdampak pada waktu yang dimiliki dan sebaiknya tidak berjalan satu waktu dengan waktu yang digunakan untuk menjalani pekerjaan sebagai karyawan.

3. Media bisnis, memutuskan apakah bisnis akan dilakukan offline atau online.

4. Ketertarikan, minat perlu diperhatikan lebih lanjut karena bagaimanapun, ketika menjalani bisnis sesuai dengan bidang yang diminati dapat mempertahankan motivasi untuk tidak berhenti berbisnis akan tetapi bisnis juga mampu tetap berjalan jika seorang mampu 


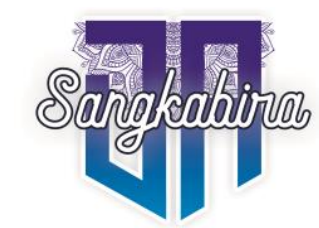

Vol. 2, No. 1, Desember 2021

mengesampingkan minat dalam berbisnis dan berfokus pada peluang dengan dedikasi penuh.

5. Dana atau modal, banyak cara untuk mendapatkan dana. Bisa dana pribadi dari tabungan ataupun dana dari sponsor.

Sedangkan hal yang menjadi perhatian ketika menjalani bisnis antara lain:

1. Adaptasi keadaan, ketika menjadi hybrid entrepreneur ada banyak hal yang perlu disesuaikan mulai dari pembagian waktu, kondisi tubuh akibat bertambahnya kegiatan, serta kondisi finansial terlebih saat bisnis pada tahap awal dimulai. Adaptasi perlu dilakukan untuk dapat menyesuaikan keadaan dan berpikiran jernih dalam memegang tanggungjawab sebagai karyawan dan pelaku usaha.

2. Manajemen waktu, hal ini sangat perlu dilakukan mengingat bertambahnya kegiatan yaitu berupa menjalani aktifitas bisnis berkaitan langsung dengan waktu yang dimiliki untuk aktifitas diluar pekerjaan semakin singkat. Maka diperlukan manajemen waktu yang dalam mengatur waktu yang ada, dimulai dari membuat tingkat prioritas pekerjaan. Hal tersebut mampu membantu dalam menyelesaikan masalah atau tanggungjawab mengacu pada tingkat urgensinya.

3. Pembagian tugas, pembagian tugas untuk diri sendiri perlu dicatat atau diberi perhatian lebih dengan tujuan tidak mencampurkan urusan pekerjaan sebagai karyawan dengan urusan sebagai pemilik bisnis.

Materi disampaikan selama 120 menit kemudian sisa waktu 40 menit digunakan sebagai sesi tanya jawab. beberapa peserta menyampaikan pertanyaan yang relevan dengan materi yang disampaikan narasumber. Hal tersbut mengindikasikan adanya feedback positif hasil komunikasi materi yang disampaikan sebagaimana dijelaskan Hardiyansyah (2015) bahwa positive feedback terjadi ketika pesan yang disampaikan oleh komunikator dapat diterima oleh komunikan dan mencapai saling pengertian, sehingga komunikan akan mendukung, mengiyakan, sepakat, setuju atas pesan. Adapun pertanyaan yang disampaikan peserta webinar dan jawaban yang diberikan narasumber adalah sebagai berikut:

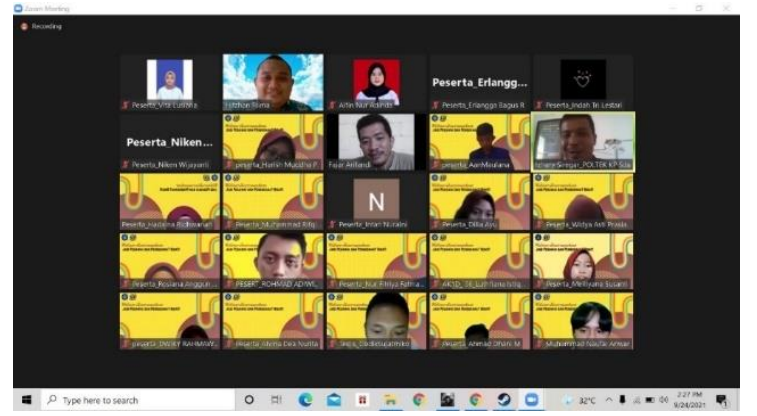

Gambar 3. Sesi tanya jawab dengan peserta webinar

(Sumber: Data Penulis)

1. Pertanyaan: Mengapa tidak keluar dari pekerjaan di BUMN dan fokus ke bisnis? 
Jawaban: Narasumber menerangkan bahwa bekerja di BUMN merupakan kebanggaan dan pencapaian tersendiri. Hal tersebut dikarenakan narasumber sangat fokus dengan pendidikannya semasa di perguruan tinggi dan memiliki keinginan untuk mendapat pekerjaan yang di linier dengan progam studi yang dijalani di perusahaan yang terkemuka sehingga setelah melalui proses seleksi ketat BUMN dan mendapatkan pekerjaan tetap di PT Angkasa Pura sesuai dengan progam studi kuliahnya, narasumber ingin mempertahankan pekerjaan tersebut.

2. Pertanyaan : Bagaimana cara melakukan riset pasar sebelum masuk ke suatu bidang bisnis?

Jawaban: Narasumber menyampaikan bahwa dalam titik perhatian melakukan riset yaitu mengawasi perilaku sekitar. Untuk mencari peluang bisnis maka perlu mengawasi kebutuhan target pasar yang tidak terpenuhi yang nantinya bisa kita penuhi dengan sumber daya maupun kemampuan yang kita miliki. Setelah mengetahui celah peluang ini, pelaku bisnis bisa memiliki gambaran mengenai produk ataupun jasa yang akan dipasarkan.

3. Pertanyaan: Sebaiknya memulai bisnis dari kapan? Saat ini (mahasiswa) atau mengumpulkan modal dulu?

Jawaban: Narasumber berpendapat bahwa bisnis bisa dimulai dari kapan pun bahkan dalam konteks sekarang, dari menjadi mahasiswa. Modal kecil dapat dikembangkan bila bisnis berjalan dan untuk memulai hal tersebut perlu keberanian mengambil peluang dan resiko. Ketika telah menjalani bisnis, seorang akan mampu mempelajari sendiri bagaimana bisnis berjalan dan mengevaluasi setiap kejadian, baik perkembangan maupun kemunduran bisnis. Hal tersebut berguna untuk menyusun rencana strategis di masa depan.

\section{Kesimpulan dan Saran \\ Kesimpulan}

Seseorang dapat memiliki lebih dari satu pekerjaan dalam rangka meningkatkan pendapatan untuk memenuhi kebutuhan, salah satunya adalah menjadi karyawan sekaligus pemilik usaha. Bagi seorang yang menempuh perguruan tinggi, mendapatkan pekerjaan sesuai bidang studi yang dipelajari di perguruan tinggi dapat menjadi kebanggaan serta alasan bertahan menjadi karyawan akan tetapi hal tersebut bukan hambatan dalam mengelola bisnis sebagai upaya menciptakan lapangan pekerjaan dan menambah pendapatan. Menjalankan pekerjaan sebagai karyawan disuatu perusahaan sekaligus mengelola usaha atau bisnis bisa dilakukan dan untuk menjaga keseimbangan pemenuhan tanggungjawab keduanya, perlu dilakukan langkah strategis dalam pengambilan keputusan sehingga pemenuhan kebutuhan bisa tercapai tanpa mengabaikan salah satu tanggungjawab, baik sebagai karyawan maupun pelaku usaha. Maka dari 


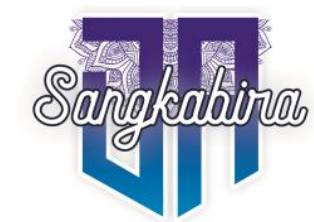

Vol. 2, No. 1, Desember 2021

itu edukasi mengenai kepemilikan lebih dari satu pekerjaan melalui webinar ini dilakukan supaya mahasiswa memiliki ilmu dalam rangka menyusun rencana strategis peluang menjadi hybrid entrepreneur di masa depan. Webinar yang telah dilaksanakan menunjukan antusiasme peserta dilihat dari pertanyaan yang diajukan, hal tersebut mengindikasikan bahwa terdapat peningkatan minat dalam hal mengetahui ilmu berwirausaha sambil menjalan pekerjaan utama sebagai karyawan.

\section{Saran}

Diharapkan kedepannya akan lebih banyak edukasi mengenai kewirausahaan kepada mahasiswa dalam upaya mengenalkan, meningkatkan, dan mengembangkan minat berwirausaha kepada mahasiswa dengan harapan mahasiswa di masa depan mampu berpartisipasi sebagai pencipta lapangan pekerjaan demi peningkatan ekonomi dan pemanfaatan sumber daya sekitar secara maksimal.

\section{Daftar Referensi}

Data Pengguna Internet, Siaran Pers: Pengguna Internet Indonesia Hampir Tembus 200 Juta di 2019 - Q2 2020. Buletin APJII. https://blog.apjii.or.id/index.php/2020/11/09/siaran-pers-penggunainternet-indonesia-hampir-tembus-200-juta-di-2019-q2-2020/. Diakses pada 30 September 2021.

Hardiyansyah, Hardi (2015) Komunikasi Pelayanan Publik Konsep dan Aplikasi. Gava Media, Yogyakarta.

Hidayah, Tamriatin (2015) Analisis Faktor-Faktor yang Mempengaruhi Minat/Intensi Kewirausahaan Mahasiswa STIE Mandala Jember. Jurnal Relasi, Jember, Pusat Penelitian dan Pengabdian Masyarakat STIE. Jember.

Hirsch, B. T., and J. V. Winters. (2016). Jerman. Rotation Group Bias in Measures of Multiple Job Holding. IZA Discussion Paper No. 10245.

Huang, L., \& Knight, A. P. (2017). Resources and relationships in entrepreneurship: an exchange theory of the development and effects of the entrepreneur-investor relationship. Academy of Management Review, 42(1), 80-102.

IFLS. (1993-2007). Indonesia family life survey. Research and Development.

Maulana, Heri. (2018). Pengembangan Jiwa Kewirausahaan: Studi Kasus Terhadap Mahasiswa yang Berwirausaha di Yogyakarta. Jurnal Ecodemica, Vol 2(1). ISSN: 2355-0295.

Meredith, Geoffrey G (2002) Kewirausahaan: Teori dan Praktek. Jakarta : Pustaka binaman presindo. hal.3,5-6.37,38,39.

Pouliakas, Konstantinos (2017). Jerman. Multiple job-holding: Career pathway or dire straits?, IZA World of Labor. Institute for the Study of Labor (IZA). Bonn, Iss. 356. 
Solesvik, M. Z. (2017). Hybrid entrepreneurship: how and why entrepreneurs combine employment with self-employment. Technology Innovation Management Review, 7(3). 33-41.

Suryana (2013) Kewirausahaan: Kiat dan Proses Menuju Sukses. Jakarta: Salemba Empat.

Thorgren, Sarah., Carin Nordstro "m, Joakim Wincent. (2013). Hybrid entrepreneurship:the importance of passion. Sweden. Baltic Journal of Management Vol. 9(3) hal 314-329.

Wilkinson, R., \& Pickett, K. (2009). The Spirit Level: Why More Equal Societies Almost Always Do Better. London: Allen Lane. 